\title{
PENGARUH UKURAN PERUSAHAAN, DAN LEVERAGE TERHADAP TINDAKAN PENGHINDARAN PAJAK (TAX AVOIDANCE) PERUSAHAAN MANUFAKTUR YANG TERDAFTAR DIBURSA EFEK INDONESIA
}

\author{
Hernadianto $^{1}$, Ahmad Junaidi ${ }^{2}$, Agus dwi prayogi ${ }^{3}$ \\ ${ }^{123}$ Fakultas Ekonomi dan Bisnis Universitas Muhammadiyah Bengkulu \\ Email : hernadianto@umb.ac.id, rasi-jundi@yahoo.com.sg ${ }^{2}$
}

\begin{abstract}
ABSTRAK
Tax avoidance adalah cara untuk menghindari pembayaran pajak secara legal yang dilakukan oleh Wajib Pajak dengan cara mengurangi jumlah pajak terutangnya tanpa melanggar aturan perpajakan atau dengan istilah lainnya mencari kelemahan peraturan, eksekutif memiliki peranan signifikan positif terhadap tax Avoidance. Tujuan penelitian ini Untuk mengetahui pengaruh ukuran perusahaan dan leverage terhadap tindakan penghindaran pajak (tax avoidance) pada perusahaan manufaktur yang terdaftar di Bursa Efek Indonesia.Penelitian ini menggunakan jenis penelitian yang digunakan dalam penelitian ini dapat digolongkan ke dalam penelitian empiris. Data yang digunakan dalam penelitian ini adalah data sekunder dari perusahaan yang terdaftar di Bursa Efek Indonesia (BEI). Hasil penelitian ini yaitu Variabel Ukuran perusahaan tidak berpengaruh terhadap penghindaran pajak. Besar kecilnya ukuran perusahaan tidak akan mempengaruhi penghindaran pajak. Karena setiap manajemen perusahaan ingin dinilai baik kinerjanya oleh pemegang saham sehingga perusahaan kecil atau besar akan melakukan penghindaran pajak. Variabel Leverage berpengaruh positif signifikan terhadap penghindaran pajak. Semakin tinggi tingkat leverage yang diperoleh perusahaan akan semakin tinggi tingkat penghindaran pajak yang dilakukan perusahaan.
\end{abstract}

Kata Kunci: Ukuran perusahaan, leverage, tax avoidance, perusahaan manufaktur

\begin{abstract}
Tax avoidance is a way to avoid paying taxes legally by taxpayers by reducing the amount of tax owed without violating tax rules or in other terms looking for regulatory weaknesses. Executives have a significant positive role in tax avoidance. The purpose of this study was to determine the effect of company size and leverage on tax avoidance in manufacturing companies listed on the Indonesia Stock Exchange.This study the type of this research can be classified into empirical research. The data used in this study were secondary data from companies listed on the Indonesia Stock Exchange (IDX).The results of this study indicate that variable Size of the company does not affect tax avoidance. The size of the company will not affect tax avoidance. Every company management wants to be assessed as good by shareholders so that small or large companies will do tax avoidance. Leverage variables have a significant positive effect on tax avoidance. The higher the level of leverage obtained by the company, the higher the level of tax avoidance by the company.
\end{abstract}

Keywords: Company size, leverage, tax avoidance, manufacturing companies 


\section{PENDAHULUAN}

Pajak adalah salah satu sumber pemasukan APBN yang paling besar. Pemasukan terbesar ini harus terus ditingkatkan secara baik supaya laju pertumbuhan negara dapat berjalan dengan baik. Dengan demikian sangat diharapkan kepatuhan wajib pajak dalam melaksanakan kewajiban perpajakannya dengan sukarela sesuai dengan peraturan perpajakan yang berlaku dinegara Indonesia. Ketidakpatuhan wajib pajak biasanya dilakukan dengan berbagai cara seperti penghindaran pajak (Maria Melisa Vivi Adeyani Tandean, 2017). Penghindaran pajak (Tax avoidance) yaitu upaya penghindaran pajak secara legal yang tidak melanggar peraturan perpajakan yang dilakukan wajib pajak dengan cara berusaha mengurangi jumlah pajak terutangnya dengan mencari kelemahan peraturan. Penghindaran pajak ini sengaja dilakukan oleh perusahaan dalam rangka memperkecil besarnya tingkat pembayaran pajak yang harus dibayarkan dan meningkatkan cash flow perusahaan. Manfaat dari adanya penghindaran pajak adalah untuk memperbesar tax saving yang berpotensi mengurangi pembayaran pajak sehingga akan menaikkan cash flow. Metode yang digunakan untuk menghindari pajak sangat bervariasi dan pada umumnya digunakan untuk menutup kebenaran, demi menghindari pajak.

Ukuran perusahaan adalah suatu skala dimana dapat diklasifikasikan besar kecil perusahaan menurut berbagai cara, antara lain : total aset, log size, nilai pasar saham, dan lain-lain. Ukuran perusahan dapat dinilaidaribeberapasegi besarkecilnyaukuranperusahaandapat didasarkan pada total nilai aset, total penjualan, kapasitas pasar, jumlah tenaga kerja dan sebagainya. Karakteristik perusahaan menjadi salah satu faktor penentu dalam pengambilan tindakan tax avoidance. Pemerintah biasanya memberikan perhatian khusus kepada perusahaan yang besar sehingga perusahaan itu mendapat tekanan untuk berlaku patuh atau agresif dalam perpajakan (Khairul Adhi Fiandri, 2017). Leverage (struktur utang) merupakan rasio yang menunjukkan besarnya utang yang dimiliki oleh perusahaan untuk membiayai aktivitas operasinya. Penambahan jumlah utang akan mengakibatkan munculnya beban bunga yang harus dibayar oleh perusahaan, komponen beban bunga akan mengurangi laba sebelum kena pajak perusahaan Sehingga beban pajak yang harus dibayar perusahaan akan menjadi berkurang. Perusahaan besar lebih cenderung memanfaatkan sumber daya yang dimilikinya daripada menggunakan pembiayaan yang berasal dari utang.Pada penelitian lain mengatakan bahwa 1). Penghindaran pajak tidak berpengaruh terhadap nilai perusahaan, 2). Leverage berpengaruh positif terhadap nilai perusahaan, dan 3). Leverage yang memoderasi penghindaran pajak tidak memberikan pengaruh terhadap nilai perusahaan. (Soerzawa, Yusmaniarti, \& Suhendra, 2018)

Penelitian terdahulu seperti Ngadiman dan Puspitasari (2014), Hendy dan Sukartha (2014), Marfu'ah (2015), Kurniasih dan Sari (2013), menyimpulkan bahwa ukuran perusahaan berpengaruh signifikan terhadap penghindaran pajak tax avoidance. Hasil penelitian ini berbeda dengan penelitian yang dilakukan oleh Rinaldi dan Cheisviyanny (2015), Sari (2014), dan Rachmithasari (2015), yang menyatakan bahwa ukuran perusahaan berpengaruh signifikan negatif terhadap penghindaran pajak tax avoidance. Peneliti terdahulu yaitu Marfu'ah (2015), Rachmithasari (2015), dan Kurniasihh dan Sari (2013), menyimpulkan 
bahwaleverage berpengaruh signifikan terhadap penghindaran pajak tax avoidance. Namun, penelitian yang dilakukan oleh Agusti (2014), Hendy dan Sukartha (2014), menyimpulkan bahwa leverage tidak berpengaruh signifikan terhadap penghindaran pajak tax avoidance yang dilakukan. Perbedaan penelitian ini dengan penelitian sebelumnya adalah pada penelitian ini variabel independen yang digunakan merupakan penggabungan dari variabel independen yang berasal dari beberapa penelitian terdahulu yaitu pengaruh ukuran perusahaan, dan leverageterhadap penghindaran pajakpada perusahaan manufaktur yang terdaftar di bursa efek indonesia pada periode 2015-2017. Berdasarkan penjelasan di atas maka peneliti ini bermaksud untuk melakukan penelitian yang lebih up to date dari penelitian sebelumnya.

\section{TINJAUAN LITERATUR}

\section{Teori Agensi}

Teori agensi ini muncul ketika terjadi sebuah kontrak antara manajer (agent) dengan pemilik (principal). Seorang manajer (agent) akan lebih mengetahui mengenai keadaan perusahaannya dibandingkan dengan pemilik (principal). manajer sebagai agent tidak selalu bertindak sesuai kepentingan pemegang saham sebagai principal. Agar manajer bertindak sesuai kepentingan pemegang saham, manajer diberi insentif yang cukup dan dengan mengeluarkan biaya monitoring untuk membatasi penyimpangan oleh manajer dalam teori keagenan, masalah keagenan timbul karena diasumsikan bahwa manajer bertindak self interest. Untuk itu muncul biaya-biaya keagenan untuk mengatasi masalah ini (Melisa \&Tandean, 2015).

Tujuan utama dengan adanya agency theory tersebut adalah untuk menjelaskan bagaimana pihak-pihak yang melakukan hubungan kontrak dapat mendesain kontrak yang tujuannya untuk meminimalisir cost sebagai dampak adanya informasi yang tidak simetris dan kondisi yang mengalami ketidakpastian. Teori keagenanjuga berusaha untuk menjawab masalah keagenan yang disebabkan karena pihak-pihak yang menjalin kerja sama dalam suatu perusahaan mempunyai tujuan yang berbeda termasuk dalam menjalankan tanggung jawabnya untuk mengelola suatu perusahaan (Jensen,Dan Meckling, 1976).

\section{Ukuran Perusahaan}

Ukuranperusahaanadalahsuatuskaladimanadapat diklasifikasikan besar kecil perusahaan menurut berbagai cara, antara lain : total aset,log size, nilai pasar saham, dan lain-lain. Ukuran perusahan dapat dinilaidaribeberapasegi.Besarkecilnyaukuranperusahaandapat didasarkan pada total nilai aset, total penjualan, kapasitas pasar, jumlah tenaga kerja dan sebagainya.

UU No. 20 Tahun 2008 membagi ukuran perusahaan ke dalam empat kategori yaitu :
a. Usaha mikro
b. Usaha kecil
c. Usaha menengah
d. Usaha besar

\section{Leverage}

Rasio ini digunakan untuk mengukur kemampuan perusahaan memenuhi kewajiban-kewajiban jangka panjangnya. Leverage mencerminkan kemampuan perusahaan dalam memenuhi seluruh kewajibannya yang 
ditunjukkan oleh beberapa bagian modal sendiri yang digunakan untuk membayar hutang (Rodoni dan Ali, 2010: 123).Menurut Kasmir (2009: 158) leverage merupakan rasio yang digunakan untuk mengetahui seberapa besar kemampuan perusahaan dalam membayarkan seluruh kewajibannya (baik kewajiban jangka pendek maupun jangka panjang).Leverage (rasio hutang) menunjukan kemampuan perusahaan untuk memenuhi kewajiban jangka panjang.

Leverage dapat dihitung melalui3 pendekatan:

a. Debt to Asset Ratio (DAR)

Rasioinimenekankanpentingnyapendanaanhutangdenganjalan menunjukkan persentase aktiva perusahaan yang didukung oleh hutang.Rasio ini juga menyediakan informasi tentang kemampuan perusahaan dalam mengadaptasi kondisi pengurangan aktiva akibat kerugian tanpa mengurangi pembayaran bunga kepada kreditor. Nilai rasio yang tinggi menunjukkan peningkatandariresikopadakreditor .

b. Debt Equity Ratio (DER)

Debt to Equity Ratio adalah rasio utang dengan ekuitas menunjukkan sejauh mana pendanaan dari utang digunakan jika dibandingkan dengan pendanaan equitas.Rasio pendanaan yang diukur dengan indikator Debt to Equity Ratio (DER) mencerminkan kemampuan perusahaan dalam memenuhi seluruh kewajibannya yang ditunjukkan oleh beberapa bagian modal sendiri yang digunakan untuk membayar hutang. Oleh karena itu, semakin rendah DER akan semakin tinggi kemampuan perusahaan untuk membayar seluruh kewajibannya.

Debt to equity ratio memberikan jaminan tentang seberapa besar hutang perusahaan dijamin oleh modal sendiri.Semakin tinggi rasio menunjukkan semakin rendah pendanaan perusahaan yang disediakan oleh para pemegang saham.

c. Long term Debt to Equity Ratio (LTDE)

Rasio ini menunjukkan perbandingan antara klaim keuangan jangka panjang yang digunakan untuk mendanai kesempatan investasi jangka panjang denganpengembalian jangka panjang pula.

\section{Penghindaran Pajak (Tax Avoidance)}

Penghindaran pajak yang juga disebut sebagai tax planning adalah proses pengendalian tindakan agar terhindar dari konsekuensi pengenaan pajak yang tidakdikehendaki. Menurut Maria Melisa Vivi Adeyani Tandean (2017) menyatakan bahwa Penghindaran pajak merupakan usaha yang dilakukan oleh wajib pajakapakah berhasil atau tidakuntuk mengurangi atau sama sekali menghapus utang pajak, yang tidak melanggar ketentuan peraturan perundang-undangan perpajakan. Tax avoidance menurut peraturan pajak tidak dilarang meskipun seringkali mendapat sorotan yang kurang baik karena dianggap memiliki konotasi negatif ataupun dianggap kurang nasionalis. Penghindaran pajak (tax avoidance) yang dilakukan oleh managemen suatu perusahaan dilakukan untuk meminimalisasi kewajiban pajak perusahaan. 


\section{METODE}

Penelitian ini dilakukan di perusahaan manufaktur yang terdaftar di Bursa Efek Indonesia periode 2015-2017 dan penelitian di lakukan pada bulan Desember 2018 sampai dengan bulan Februari 2019.Jenispenelitianyangdigunakandalampenelitianinidapatdigolongkan ke dalampenelitian empiris.Populasi dalam penelitian ini ialah perusahaan manufaktur yang listed dan terdaftar di Bursa Efek Indonesia dari tahun 2015-2017. Sampel dipilih dengan menggunakan metode purposive sampling dengan berdasarkan pertimbangan (judgement sampling)sebanyak 33 perusahaan dengan jumlah observasi sebanyak 158 observasi.Data yang digunakan dalam penelitian ini adalah data sekunder dari perusahaan yang terdaftar di Bursa Efek Indonesia (BEI).Teknik analisis data dalam penelitian ini menggunakan statistik dengan teknik Analisis Regresi Linear berganda, dengan metode Statistical Product and Service Solution (SPSS). Tahap yang dilakukan adalah Statistik Deskriptif, Uji Asumsi Klasik, dan Uji Hipotesis. Untuk Mendeteksi adanya penyimpangan asumsi klasik maka dilakukan uji normalitas, Uji multikolonieritas,Uji heteroskedastisitas, dan Uji autokorelasi

\section{HASIL DAN PEMBAHASAN}

\section{Hasil Uji Normalitas}

Penelitian ini menggunakan uji kolmogorov-smirnov (1 Sampel K-S) dengan tingkat kepercayaan 5\%, apabila tingkat signifikannya melebihi 0,05 maka data tersebut terdistribusi secara normal. Hasil Uji Normalitas data dapat dilihat pada table 4.4 berikut ini :

\section{Tabel 1}

One-Sample Kolmogorov-Smirnow Test

\begin{tabular}{|ll|r|}
\hline & & $\begin{array}{c}\text { Unstandardiz } \\
\text { ed Residual }\end{array}$ \\
\hline N & Mean & 89 \\
Most Extreme Differences & .0000000 \\
& Std. Deviation & .11515407 \\
& Absolute & .198 \\
& Positive & .198 \\
Kolmogorov-Smirnov $Z$ & Negative & -.099 \\
Asymp. Sig. (2-tailed) & & 1.866 \\
\hline
\end{tabular}

a. Test distribution is Normal.

Hasil yang diperoleh nilai uji normalitas dalam penelitian ini 0,002 yang mana lebih kecil dari 0.05, Pengujian terhadap uji normalitas menunjukkan hasil bahwa data tidak berdistribusi normal berarti data tersebut tidak normal. Namun merujuk pada asumsi Central LimitTheorem yang menyatakan bahwa untuk sampel yang besar terutama lebih dari $30(\mathrm{n} \geq 30)$, distribusi sampel dianggap mendekati distribusi normal (Dielman, 1961), yang berarti bahwa walaupun dari pengujian asumsi klasik berupa pengujian normalitas menunjukkan semua data berdistribusi tidak normal namun karena observasi lebih dari $30(\mathrm{n} \geq 30)$ maka data 
tersebut tetap dianggap normal, karena menggunakan 33 perusahaan (selama tiga tahun) yang menjadi 99 sampel untuk dianalisa.

\section{Uji Multikolonieritas}

Uji multikolonieritas ini bertujuan untuk menguji apakah di dalam model regresi terdapat korelasi antara variabel bebas (independennya). Hasil Uji multikolonieritas dapat dilihat pada tabel 4.5 berikut ini :

Tabel 2

\begin{tabular}{|c|c|c|c|c|c|c|c|c|}
\hline \multicolumn{9}{|c|}{ Coefficients $^{\mathrm{a}}$} \\
\hline \multirow{2}{*}{\multicolumn{2}{|c|}{ Model }} & \multicolumn{2}{|c|}{ Unstandardized Coefficients } & \multirow{2}{*}{$\begin{array}{c}\begin{array}{c}\text { Standardized } \\
\text { Coefficients }\end{array} \\
\text { Beta }\end{array}$} & \multirow[b]{2}{*}{$t$} & \multirow[b]{2}{*}{ Sig. } & \multicolumn{2}{|c|}{ Collinearity Statistics } \\
\hline & & $\mathrm{B}$ & Std. Error & & & & Tolerance & VIF \\
\hline \multirow[t]{3}{*}{1} & (Constant) & .321 & .226 & & 1.422 & .159 & & \\
\hline & UP & -.003 & .008 & -.045 & -.428 & .670 & .980 & 1.021 \\
\hline & LEVERAGE & .059 & .022 & .274 & 2.612 & .011 & .980 & 1.021 \\
\hline
\end{tabular}

a. Dependent Variable: PENGHINDARAN.PAJAK

Dari tabel 2 di atas dapat dilihat bahwa tidak ada satupun variabel independen yang memiliki nilai toleransi di bawah 0,10 dan nilai VIF di atas 10. Maka dapat disimpulkan bahwa di dalam model regresi tidak ditemukan adanya korelasi antara variabel independennya.

\section{Uji Heteroskedastisitas}

Heteroskedastisitas dapat diketahui melalui uji Glejser (Glejser Test).Uji heteroskedastisitas ini dilakukan dengan menganalisis regresi variabel independen terhadap nilai absolut residualnya. Hasil uji heteroskedistisitas dapat dilihat pada tabel 3 berikut ini:

Tabel 3

Coefficients

\begin{tabular}{|c|c|c|c|c|c|c|}
\hline \multirow{2}{*}{\multicolumn{2}{|c|}{ Madel }} & \multicolumn{2}{|c|}{ Unstandardized Coefficients } & \multirow{2}{*}{$\begin{array}{c}\begin{array}{c}\text { Standardized } \\
\text { Coefficients }\end{array} \\
\text { Beta }\end{array}$} & \multirow[b]{2}{*}{$t$} & \multirow[b]{2}{*}{ Siq. } \\
\hline & & B & Std. Error & & & \\
\hline \multirow[t]{3}{*}{1} & (Constant) & .048 & .113 & & .420 & .676 \\
\hline & UP & .000 & .004 & -.003 & -.032 & .975 \\
\hline & LEVERAGE & .020 & .011 & .193 & 1.803 & .075 \\
\hline
\end{tabular}

a. Dependent Variable: abs2

Uji heteroskedastisitas yaitu apabila nilai signifikansi probabilitas variabel berada di atas 0,05 . Berdasarkan hasil uji heteroskedastisitas di atas dapat dilihat bahwa setiap variabel ukuran perusahaan dan leverage signifikansinya di atas 0,05, maka dapat di simpulkan bahwa data yang digunakan dalam penelitian ini terbebas dari heteroskedastisitas.

\section{Uji Autokorelasi}

Uji autokorelasi bertujuan untuk menguji apakah didalam model regresi terdapat korelasi.Menurut Ghozali (2005: 91) model regresi yang baik adalah bebas dari autokorelasi.Untuk mengetahui ada atau tidaknya autokorelasi maka dilakukan uji Durbin Watson.Hasil pengujian dapat dilihat pada tabel 4.berikut ini : 
Tabel 4

Model Summary

\begin{tabular}{|l|l|r|r|r|r|}
\hline $\begin{array}{l}\text { Mode } \\
1\end{array}$ & $\mathrm{R}$ & $\mathrm{R}$ Square & $\begin{array}{c}\text { Adjusted R } \\
\text { Square }\end{array}$ & $\begin{array}{c}\text { Std. Error of } \\
\text { the Estimate }\end{array}$ & $\begin{array}{c}\text { Durbin- } \\
\text { Watson }\end{array}$ \\
\hline 1 & $.271 \mathrm{a}$ & .074 & .052 & .11649 & 1.990 \\
\hline
\end{tabular}

a. Predictors: (Constant), LEVERAGE, UP

b. Dependent Variable: PENGHINDARAN.PAJAK

Berdasarkan tabel 4 di atas dapat dilihat DW Test dengan nilai tabel menggunakan nilai signifikansi $5 \%$, jumlah sampel (n) sebanyak 89, dan jumlah variabel independen $2(\mathrm{~K}=2)$ diperoleh nilai dl 1.612, du 1.703 , dan $4-d u(4-1.703=2.297)$. Angka ini dapat dinyatakan du $1.703<$ dw $1.990<4-d u 2.297$. Oleh karena itu nilai dw 1.990 terletak diantara batas atas (du) 1.703 dan dibawah 4-du 2.297 maka dapat disimpulkan bahwa tidak terdapat autokorelasi antara residual pada variabel dalam penelitian ini.

\section{Pengujian Hipotesis}

Pengujian hipotesis bertujuan untuk mengetahui Pengaruh Ukuran Perusahaan, Dan Leverage Terhadap Penghindaran Pajak (Tax Avoidance). Dengan menggunakan penghindaran pajak sebagai variabel dependen dan ukuran perusahaandan leverage sebagai variabel independen.

\section{Uji Koefisien Determinasi (R2)}

Menurut Ghozali (2012: 97) koefisien determinasi (R2) merupakan alat untuk mengukur seberapa jauh kemampuan model dalam menerangkan variasi variabel dependen.Nilai koefisien determinasi adalah antara nol atau satu.Nilai R2 yang kecil berarti kemampuan variabel-variabel independen dalam menjelaskan variasi variabel dependen amat terbatas.Dan sebaliknya jika nilai yang mendekati 1 berarti variabel-variabel independen memberikan hampir semua informasi yang dibutuhkan untuk memprediksi variabel-variabel dependen.dilihat pada tabel 5 berikut ini:

\section{Tabel 5}

Model Summary

\begin{tabular}{|l|l|r|r|r|r|}
\hline $\begin{array}{l}\text { Mode } \\
\perp\end{array}$ & R & R Square & $\begin{array}{c}\text { Adjusted R } \\
\text { Square }\end{array}$ & $\begin{array}{c}\text { Std. Error of } \\
\text { the Estimate }\end{array}$ & $\begin{array}{c}\text { Durbin- } \\
\text { Watson }\end{array}$ \\
\hline 1 & $.271^{2}$ & .074 & .052 & .11649 & 1.990 \\
\hline
\end{tabular}

a. Predictors: (Constant), LEVERAGE, UP

b. Dependent Variable: PENGHINDARAN.PAJAK

Menunjukkan bahwa besarnya nilai adjusted $\mathrm{R}$ adalah 0,074 atau 7,4\%. Hal ini menunjukkan bahwa variabel dependen dalam penelitian ini yaitu penghindaran pajak dapat dijelaskan oleh variabel independen sebesar 7,4\% yang terdiri dari ukuran perusahaan, dan leverage dan 92,6\% sisanya dipengaruhi oleh faktor lain yang tidak diuji dalam penelitian ini.

\section{Uji T (Uji Parsial)}

Uji $\mathrm{T}$ digunakan untuk menguji secara parsial masing-masing variabel independen yaitu ukuran perusahaan, dan leverage. Hasil uji t dapat dilihat pada tabel koefisien pada kolom sig. Hasil pengujian tersebut dapat dilihat pada tabel 6 : 
Tabel 6

\begin{tabular}{|c|c|c|c|c|c|c|c|c|}
\hline \multicolumn{9}{|c|}{ Coefficients $^{3}$} \\
\hline \multirow[b]{2}{*}{ Model } & & \multicolumn{2}{|c|}{ Unstandardized Coefficients } & \multirow{2}{*}{$\begin{array}{c}\begin{array}{c}\text { Standardized } \\
\text { Coefficients }\end{array} \\
\text { Beta } \\
\end{array}$} & \multirow[b]{2}{*}{$t$} & \multirow[b]{2}{*}{ Siq. } & \multicolumn{2}{|c|}{ Collinearity Statistics } \\
\hline & & $\mathrm{B}$ & Std. Error & & & & Tolerance & VIF \\
\hline 1 & (Constant) & .321 & .226 & & 1.422 & .159 & & \\
\hline & UP & -.003 & .008 & -.045 & -.428 & .670 & .980 & 1.021 \\
\hline & LEVERAGE & .059 & .022 & .274 & 2.612 & .011 & .980 & 1.021 \\
\hline
\end{tabular}

Berdasarkan tabel 4.10 dapat diketahui bahwa nilai Thitung variabel ukuran perusahaan lebih kecil dari Ttabel yaitu $-0.045<1.662$ sedangkan nilai Thitung variabel leverage lebih besar dari Ttabel yaitu 2.612 $>1.662$, artinya hipotesis yang menyatakan ada pengaruh ukuran perusahaan terhadap penghindaran pajak (tax avoidance) ditolak. sedangkanhipotesis yang menyatakan ada pengaruh leverage terhadap penghindaran pajak (tax avoidance) diterima.

\section{PEMBAHASAN}

\section{Hipotesis (H1) dan Pembahasan}

Hipotesis (H1) dalam penelitian ini menyebutkan bahwa ada pengaruh ukuran perusahaan terhadap penghindaran pajak.Hasil pengujian ini diperoleh bahwa nilai Thitung variabel ukuran perusahaan lebih kecil dari Ttabel yaitu $-0.045<1.662$ sedangkan nilai sig $0.670>0.05$, ketentuan pengambilan keputusan hipotesis diterima atau ditolak berdasarkan pada besarnya nilai signifikansi dan nilai Ttabel.Jika nilai signifikansi lebih kecil dari 0.05 maka hipotesis diterima, dan jika Ttabel > Tthitung begitu, juga sebaliknya apabila nilai signifikansi lebih besar dan Ttabel $<$ Tthitung maka hipotesis ditolak.

Hasil penelitian ini diperoleh nilai signifikansi sebesar 0.670 lebih besar dari 0.05 maka disimpulkan bahwa hipotesis (H1) ditolak. Hal inimembuktikan bahwa besar kecilnya ukuran perusahaan tidak akan mempengaruhi penghindaran pajak. Suatu perusahaan yang besar pasti akan mendapat perhatian lebih besar dari pemerintah terkait dengan asset, laba dantingkat penjualan yang diperoleh, sehingga perusahaan yang besar tersebut sering menarik perhatian fiskus(administrasi pajak) untuk dikenai pajak sesuai aturan yang berlaku. Tidak berpengaruhnya variabel ini disebabkan karena membayar pajak merupakan kewajiban bagi semua warga negara dan badan atau perusahaan. sesuai dengan teori agensi, bahwa manajemen ingin dinilai baik dalam kinerjanya oleh pemegang saham. Sehingga ukuran perusahaan yang kecil maupun besar tidak mempengaruhi manajemen untuk tidak melakukan penghindaran pajak. Pemerintah biasanya memberikan perhatian khusus kepada perusahaan yang besar sehingga perusahaan itu mendapat tekanan untuk berlaku patuh atau agresif dalam perpajakanSemakin besar ukuran perusahaannya, maka transaksi yang dilakukan akan semakin kompleks. Selain itu perusahaan yang beropersi lintas negara memiliki kecenderungan untuk melakukan tindakan tax avoidance yang lebih tinggi dibandingkan perusahaan yang beroperasi lintas domestik karena mereka bisa melakukan transfer laba ke perusahaan yang berada di negara lain. Dimana negara tersebut memungut tarif pajak yang lebih rendah dibandingkan negara lainnya. 
Hasil penelitian ini mendukung penelitian yang dilakukan oleh Silvia dan Puji (2014) yang menyatakan bahwa variabel ukuran perusahaan tidak berpengaruh signifikan terhadap penghindaran pajak.Karena usaha penghindaran pajak dilakukan baik pada perusahaan kecil maupun besar. Serta penelitian ini sejalan dengan penelitian Silvia \& Puji (2014) yang menyataan bahwa ukuran perusahaan tidak berpengaruh signifikan terhadap penghindaran pajak. Karena perusahaan kecil maupun besar mempunyai kewajiban penuh dalam pembayaran pajak kepada negara. Serta semakin besarnya perusahaan akan semakin tinggi dalam pengawasan kinerja perusahaan.

Berbeda dengan penelitian yang dilakukan Swingly (2015) yang menyimpulkan bahwa ukuran perusahaan berpengaruh signifikan terhadap penghindaran pajak. Semakin besarnya ukuran suatu perusahaan akan semakin memungkinkan perusahaan untuk mengatu perpajakan dengan melakukan tax planninguntuk mencapai tax savingyang optimal bagi perushaannya.

\section{Hipotesis (H2) dan Pembahasan}

Hipotesis (H2) dalam penelitian ini menyebutkan bahwa leverageberpengaruh signifikan terhadappenghindaran pajak. Menurut Annisa, (2017) leverage adalah salah satu rasio keuangan yang menggambarkan hubungan antara hutang perushaaan terhadap modal maupun aset perusahaan. Rasioleveragemenggambarkan sumber dana operasi yang digunakan oleh perusahaan. Rasioleverage juga menunjukan risiko yang dihadapi perusahaan. Hasil pengujian ini diperoleh nilai leverage memiliki t hitung sebesar 2.612 dan tingkat signifikan sebesar 0.011ketentuan pengambilan keputusan hipotesis diterima atau ditolak didasarkan pada besarnya nilai signifikansi.Hasil penelitian ini diperoleh nilai signifikansi sebesar 0.011 lebih kecil dari 0.05 maka disimpulkan bahwa hipotesis $(\mathrm{H} 2)$ yaitu leverage berpengaruh signifikan terhadap penghindaran pajak pada perusahaan manufaktur yang terdaftar di Bursa Efek Indonesia, hal ini mengidentifikasikan bahwa kecilnya nilaileverageyang dimiliki perusahaan berpengaruh terhadap penghindaran pajak. Hal ini berarti bahwa Leverageyang diukur menggunakan DER terbukti berpengaruh positif terhadap penghindaran pajak, artinya bahwa semakin tinggi tingkat leverage yang diperoleh perusahaan akan semakin tinggi tingkat penghindaran pajak. Karena semakin tingginya nilai leverage semakin tinggi pendanaan yang berasal dari hutang pihak ketiga yang digunakan oleh perusahaan. Maka dengan adanya jumlah hutang akan menyebabkan munculnya beban bunga yang harus dibayar oleh perusahaanBeban bunga yang timbul karena adanya hutang, akan mengurangi jumlah beban pajak perusahaan. Beban bunga yang dapat digunakan sebagai pengurang laba kena pajak adalah beban bunga yang muncul akibat adanya pinjaman kepada pihak ketiga atau kreditur yang tidak memiliki hubungan dengan perusahaan. Hal tersebut memberikan pengaruh terhadap penghindaran pajak.

Hasil penelitian ini mendukung hasil penelitian yang dilakukan oleh Swingly (2015)yang menyatakan bahwa leverageberpengaruh signifikan terhadap penghindaran pajak. Perusahaan yang memiliki hutang tinggi akan mendapatkan insentif pajak berupa potongan atas bunga pinjaman.Hal ini sesuai dengan pasal6 ayat (1) huruf a Undang-Undang No 36 tahun 2008 menyebutkan bahwa bunga 
hutang dapat dikurangkan dengan tujuan perhitungan perpajakan. Sehingga peraturan ini sebagai celah oleh perusahaan untuk melakukan penghindaran pajak dengan cara menambahkan hutang perusahaan guna memperoleh insentif pajak. Berbeda dengan penelitian yang dilakukan oleh Puspita \& Ngadiman (2014) dan Darmawan \& Sukartha (2014) bahwa leverage tidak berpengaruh signifikan terhadap penghindaran pajak, karena sesuai dengan teori trade off menyatakan bahwa penggunaan hutang oleh perusahaan dapat digunakan untuk menghemat pajak dengan memperoleh insentif berupa beban bunga yang akan menjadi pengurang penghasilan kena pajak. Keputusan pendanaan perusahaan menjadi gambaran penghindaran pajak terkait dengan tarif pajak efektif, hal tersebut dikarenakan ada peraturan perpajakan terkait struktur pendanaan perusahaan. Keputusan pendanaan yang dimaksud adalah perusahaan lebih menggunakan pendanaan internal atau eksternal. Perusahaan sampel memiliki hutang yang sebagian besar berasal dari pinjaman modal kepada pemegang saham, sehingga beban bunga yang ditimbulkan tidak dapat diguakan sebagai pengurang laba kena pajak perusahaan.

\section{KESIMPULAN DAN SARAN}

\section{Kesimpulan}

Variabel Ukuran perusahaan tidak berpengaruh terhadap penghindaran pajak. Besar kecilnya ukuran perusahaan tidak akan mempengaruhi penghindaran pajak. Karena setiap manajemen perusahaan ingin dinilai baik kinerjanya oleh pemegang saham sehingga perusahaan kecil atau besar akan melakukan penghindaran pajak.Variabel Leverage berpengaruh positif signifikan terhadap penghindaran pajak. Semakin tinggi tingkat leverage yang diperoleh perusahaan akan semakin tinggi tingkat penghindaran pajak yang dilakukan perusahaan.

\section{Saran}

Untuk penelitian sejenis disarankan agar menggunakan atau menambah variabel lain yang bias mempengaruhi penghindaran pajak, serta disarankan supaya mempertimbangkan masa penelitian yang lebih lama, supaya sampel yang diperoleh lebih banyak dan lebih akurat.

\section{DAFTAR PUSTAKA}

Alfian, Nurul \& Ah.Suryansyah. 2017. Pengaruh Efektivitas Komite Audit, Ukuran Perusahaan dan Leverage Terhadap Pemilihan Auditor Eksternal. Aktiva Jurnal Akuntansi dan Investasi. Jurnal Akuntansi Dan Investasi Universitas Madura Vol 2, No 2, Nov 2017.

Annisa. 2017. Pengaruh Return On Asset, Leverage, Ukuran Perusahaan Dan Koneksi Politik Terhadap Penghindaran Pajak. Fakultas Ekonomi Universitas Riau, Pekanbaru, Indonesia.

Asri, Ida Yu Trisna Yudi \& Ketut Ali Suardana. 2016. Pengaruh Proporsi Komisaris Independen, Komite Audit, Preferensi Risiko Eksekutif Dan Ukuran Perusahaan Pajak. ISSN: 2302-8556 E-Jumal Akutansi Universitas Udayana Vol. 16.1 Juli: 72-100.

Fiandri, Khairul Adhi \& Dulmaid.2017. Pengaruh Kepemilikan Institusional Dan Ukuran Perusahaan Terhadap Tax Avoidance Dengan Kinerja Keuangan Sebagai Variabel Mediasi Pada Perusahaan Manufaktur. Volume 6, Nomor 2, Flalaman 1-13 Issn (Online): 2337-3806.

Ghozali, Imam. 2012. Aplikasi Analisis Multivariate Dengan Program IBM SPSS 20. Semarang: Badan Penerbit - Universitas Diponegoro. 
Ghozali, Imam. 2013. Aplikasi Analisis multivariate Dengan Program IBM SPSS 21 Update PLS Regresi. Semarang: Badan Penerbit Universitas diponegoro.

Jensen \& Meckling, 1976, The Theory Of The Firm: Manajerial Behaviour, Agency Cost, And Ownership Structure. Journal Of Financial And Economics, 3: 305-360.

Oktamawati, Mayarisa. 2017. Pengaruh Karakter Eksekutif, Komite Audit, Ukuran Perusahaan, Leverage, Pertumbuhan Penjualan, Dan Profitabilitas Terhadap Tax Avoidance Jurnal Akuntansi Bisnis. Universitas Katolik Soegijapranata.

Puspita, Silvia Ratih., Dan Puji Harto. (2014). Pengaruh Tata Kelola Perusahaan Terhadap Penghindaran Pajak. Diponegoro Journal Of Accounting3(2): 1- 13.

Putri, Vidiyana Rizal \& Belia Irwansyah Putra. 2017. Pengaruh Leverage, Profitability, Ukuran Perusahaan Dan Proporsi Kepemilikan Institusional Terhadap Tax Avoidance. STIE Indonesia Banking School: Jakarta.

Swingly, Calvin Dan I Made Sukartha. Pengaruh Karakter Eksekutif, Komite Audit, Ukran Perusahaan, Leverage, Dan Sales Growth Pada Tax Avoidance. ISSN: 2302-8556 E-Jumal Akutansi Universitas Udayana 10.1 (2015): 47-62.

Sari, Gusti Maya. 2014. Pengaruh Corporate Governance, Ukuran Perusahaan, Kompensasi Rugi Fiskal Dan Struktur Kepemilikan Terhadap Tax Avoidance (Studi Empiris Pada Perusahaan Manufaktur Yang Terdaftar Di BEI Tahun 2008-2012).Jurnal Akuntansi Universitas Negeri Padang.Vol. 2, No. 3.

Soerzawa, D., Yusmaniarti, Y., \& Suhendra, C. (2018). PENGARUH PENGHINDARAN PAJAK TERHADAP NILAI PERUSAHAAN DENGAN LEVERAGE SEBAGAI VARIABEL MODERASI. Bilancia : Jurnal Ilmiah Akuntansi,, 2(4), 367-377.

Sarra, Hustna Dara. 2017. Pengaruh Konservatisme Akuntansi, Komite Audit Dan Dewan Komisaris Independen Terhadap Penghindaran Pajak. Fakultas Ekonomi Dan Bisnis Universitas Muhammadiyah Tangerang.

Sugiyono, 2013.Metodelogi Penelitian Kuantitatif, Kualitatif Dan R\&D. (Bandung: Alfabeta).

Soegijapranata, Theresia Dwi Hastuti Unika. Hubungan Antara Good Corporate Governance Dan Struktur Kepemilikan Dengan Kinerja Keuangan. Sna Viii Solo, 15-16 September 2005.

Undang-Undang Nomor 6 Tahun 1983 Tentang Ketentuan Umum Dan Tata Cara Perpajakan.

Undang-Undang Republik Indonesia Nomor 20 Tahun 2008 Tentang Usaha Mikro, Kecil, Dan Menengah. 